\title{
Importance of Different Variables for Enhancing In Situ Detection of PCR-amplified DNA
}

\author{
Gerard J. Nuovo, ${ }^{1,2}$ Frances Gallery, ${ }^{1}$ Ruth Hom, ${ }^{3}$ Phyllis MacConnell, ${ }^{1}$ and Will Bloch ${ }^{4}$
}

Departments of ${ }^{1}$ Pathology, ${ }^{2}$ Obstetrics and Gynecology, and ${ }^{3}$ Medicine, State University of New York at Stony Brook, Stony Brook, New York 11794; ${ }^{4}$ Applied Biosystems, Inc., Foster City, California 94404

\begin{abstract}
This study determined the effects of several variables on the in situ signal after PCR amplification in fixed cells. A signal was evident in all human peripheral blood monocytes fixed in buffered formalin using primers for the human proto-oncogene bcl-2 with in situ PCR only after prolonged fixation and protease digestion. A much lower detection rate was noted after ethanol or acetone fixation due to loss of amplified product out of the nucleus into amplifying solution. This observation demonstrates the importance of cross-linking fixatives for retention of amplified DNA at the site of origin. The increased amount of target-specific DNA synthesis evident with the manual hot start modification to in situ PCR was also seen with chemical hot start mediated by the Escherichia coll single-stranded DNA-binding protein. The manual hot start method strongly suppressed in situ unwanted DNA synthesis dictated by nonsense primers; residual nonspecific synthesis was infiuenced by annealing temperatures and postfixation protease dlgestion conditions.
\end{abstract}

D irect correlation of nucleic acid analysis with the histological features of the sample is the key advantage of in situ hybridization. However, the relatively high detection threshold of in situ hybridization, estimated to be $\sim 10$ copies per cell, has limited its utility. ${ }^{(1,2)}$ Amplification of target-specific sequences by PCR allows nonisotopic detection of single target molecules if the hot start method is used. ${ }^{(3)}$ However, DNA extraction prior to solution-phase PCR does not permit cellular localization of the amplified product. $^{(4)}$

Several reports have described techniques whereby the extreme sensitivity of PCR is combined with the cell-localizing ability of in situ hybridization. ${ }^{(5-11)}$ To enhance both the sensitivity and the specificity of in situ PCR and PCR in situ hybridization, we developed a manual hot start modification, where an essential reagent is withheld until the reaction temperature reaches at least $55^{\circ} \mathrm{C} .{ }^{(8,9)}$ This advance has obviated the need for the multiple primer pairs or tailed primers described by other investigators. ${ }^{(5,6)}$

Retention of the amplified product at its site of origin is essential for successful in situ detection of PCR-amplified DNA and cDNA. The impetus for using multiple primer pairs and tailed primers was that they dictated the synthesis of overlapping amplified fragments. ${ }^{(5,6)}$ It was theorized that the resultant large $(>1000 \mathrm{bp}$ ) product was detected in situ because it resisted diffusion from its nuclear site of origin, whereas the smaller (450 bp) fragments were membrane-permeant. Two observations have suggested that under certain conditions there is minimal migration of amplified product from its site of origin irrespective of size. First, amplified HIV-1-specific DNA sequences as small as 115 bp localized in situ to the nucleus in lymphocytes from AIDS patients and in infected cell lines. ${ }^{(9,11)}$ In addition, amplified cDNA from either RNA viruses or human $\mathrm{mR}$ NAs showed distinct subnuclear and cytoplasmic localization. ${ }^{(12)}$ However, we have noted that certain fixatives, such as ethanol and acetone, which support standard $P C R^{(13)}$ appear to hinder successful in situ PCR. It is unclear whether this observation reflects loss of amplified product out of the cell or inhibition of PCR in the cell.

The purpose of the present work was to define better the conditions that enhance the in situ localization of PCR-amplified DNA. These analyses documented the importance of various fixatives, fixation time, and protease digestion on retention of the amplified product as well as on nontarget DNA synthesis. Advantageous concentrations of various amplification reagents were determined, as was the utility of a single-stranded DNAbinding protein (SSB) in enhancing the convenience and the sensitivity of the technique when the manual hot start technique was not used. These results in conjunction with prior work on a wide variety of primer pairs ${ }^{(7,9,11,12)}$ suggest that the conditions of fixation and protease digestion described in this work lend themselves to a generalized protocol for enhancing the specificity and sensitivity of the PCR in situ assay.

\section{MATERIALS AND METHODS \\ Cells and Targets Studied}

Peripheral blood monocytes (PBMs) 
taken from a healthy volunteer were isolated from a Ficoll gradient (Histopaque 1077, Sigma Diagnostics, St. Louis, MO). About 5000 cells were placed on silanecoated glass slides (ONCOR, Gaithersburg, MD) using a cytospin centrifuge ( $900 \mathrm{rpm}$ for $2 \mathrm{~min}$ ); the cells were then fixed in acetone, 95\% ethanol, and $10 \%$ neutral buffered formalin (10\% formalin in $0.1 \mathrm{M}$ sodium phosphate buffer at $\mathrm{pH}$ 7.0 ), or Bouin's solution (75 parts saturated picric acid 25 parts $40 \%$ formaldehyde in water, and 5 parts glacial acetic acid; at $\mathrm{pH}$ 1.6). By placing two cytospins on a slide, direct comparisons of paired experimental conditions were done. Protease digestion, when used, was done after fixation. Pepsin (Life Technologies, Gaithersburg, MD) digestion was done in $0.01 \mathrm{~N} \mathrm{HCl}$ at room temperature; the concentration was $2 \mathrm{mg} / \mathrm{ml}$ and the time 12 min unless otherwise indicated. Proteinase $\mathrm{K}$ (ONCOR) digestion at $1 \mathrm{mg} / \mathrm{ml}$ for 12 min was done in water. Also studied was the human cervical cancer cell line SiHa (ATCC HTB 35), which contains one integrated copy of human papillomavirus (HPV) 16 DNA per cell. ${ }^{(14)}$ The SiHa cells were fixed for $15 \mathrm{hr}$ in buffered formalin and embedded in paraffin; multiple $4 \mu \mathrm{m}$ sections were placed on glass slides. The PCR primers were specific for a region of the oncogene bcl-2, which should be detectable in all PBMs, the type-specific E6 region of HPV 16, and the nucleocapsid region of the measles virus. Also employed was a Burkitt's lymphoma cell line (ATCC VR-603) which contains EBV DNA. These were mixed with oral squamous cells to demonstrate the specificity of the in situ PCR signal when using EBV-specific primers. Primer sequences are listed in Table 1.

\section{In Situ PCR}

In situ PCR refers to the technique whereby (digoxigenin) labeled nucleotide is directly incorporated into the amplified product in fixed cells. Our technique, which includes the manual hot start modification, has been described previously. ${ }^{(8-12)}$ Briefly, $7.5 \mu \mathrm{l}$ of the amplifying solution, containing buffer (GeneAmp kit, Perkin-Elmer Cetus Corporation, Norwalk, CT), $4.5 \mathrm{~mm}$ $\mathrm{MgCl}_{2}$, and $1 \mu \mathrm{M}$ each of primers, $200 \mu \mathrm{M}$ dNTPs and $10 \mu \mathrm{M}$ digoxigenin -11-dUTP (Boehringer Mannheim, Indianapolis, IN), was placed over the fixed cells on

TABLE 1 Sequences of the Primers Used in This Study

\begin{tabular}{|c|c|c|}
\hline Target $^{\mathrm{a}, \mathrm{b}}$ & Sequence & Product size/reference (bp) \\
\hline \multicolumn{3}{|l|}{ HPV 16} \\
\hline primer 1 nt 110 & 5'-CAGGACCCACAGGAGCGACC & $449^{(7)}$ \\
\hline primer 2 nt 559 & 5'-TTACAGCTGGGTTTCTCTAC & \\
\hline \multicolumn{3}{|l|}{ bcl-2 } \\
\hline primer 1 nt 2779 & 5'-CATTTCCACGTCAACAGAATTG & $504^{c}$ \\
\hline primer 2 nt 3283 & 5'-AGCACAGGATTGGATATTCCAT & \\
\hline \multicolumn{3}{|l|}{ Measles } \\
\hline primer 1 nt 115 & 5'-GTGTAATAATATCATGGTTA & $434^{(23)}$ \\
\hline primer 2 nt 549 & 5'-СТСТCСАATCTAAATTCACC & \\
\hline
\end{tabular}

${ }^{a}$ The EBV-specific primers used in this study were published by Saito et al. ${ }^{(24)}$

' $\mathrm{nt}=$ nucleotide position of primer 5 ' end in the GenBank sequence.

'Kindly supplied by Dr. Ernest Kawasaki.

the glass slide and covered with a plastic coverslip, which was then anchored to the slide with nail polish. The slide was placed in an aluminum foil "boat," which was placed directly on the sample block of a thermal cycler (Perkin Elmer Corporation). Two and one-half microliters of the DNA amplifying solution containing 2.0 units of Taq DNA polymerase (AmpliTaq DNA polymerase, Perkin Elmer Corporation) was withheld from the initial amplifying solution. When the temperature of the heating block reached $65^{\circ} \mathrm{C}$, the coverslip was partially lifted and the enzyme added. The slide was then overlaid with $\sim 1 \mathrm{ml}$ of mineral oil preheated to $82^{\circ} \mathrm{C}$. After an initial denaturing step of $94^{\circ} \mathrm{C}$ for $3 \mathrm{~min}, 20$ cycles were accomplished using the following protocol: annealing/extension at $55^{\circ} \mathrm{C}$ for $2 \mathrm{~min}$ and denaturation at $94^{\circ} \mathrm{C}$ for 1 min. The mineral oil was removed with a 2 min xylene wash, and the xylene was then removed with a 2 -min $100 \%$ ethanol wash. Detection of digoxigenin incorporated into PCR product was done with alkaline phosphatase-conjugated antidigoxigenin-labeled antibody at a 1:50 dilution according to the manufacturer's protocol (Boehringer Mannheim). The alkaline phosphatase-based colorimetric detection method used the chromogen nitroblue tetrazolium (NBT) which, in the presence of 5-bromo-4chloro-3-indolylphosphate (BCIP), yields a purple-blue precipitate as the marker of a positive cell. The counterstain, nuclear fast red (ONCOR), stains nuclei pale pink and does not stain cytoplasm.

\section{PCR In Situ and Southern Blot} Hybridizations

In PCR in situ hybridization, the unla- beled amplified DNA is detected using a labeled probe. The two methods use the same amplification, detection, and staining procedures except that digoxigenin dUTP is omitted from the PCR reagents when a labeled probe is to be used. Our high-stringency in situ hybridization protocol has been published previously. ${ }^{(15)}$ A digoxigenin-labeled genomic HPV 16 probe made by the random primer method (Genius kit, Boehringer Mannheim) was used for detection of amplified HPV 16 DNA. Southern blot hybridization analysis of amplified $b c l-2$ specific sequences in the amplifying solution and cellular extract was done with a ${ }^{32}$ P-labeled oligonucleotide internal fragment that spanned nucleotides 2977-2992, using a previously reported protocol. $^{(16)}$

\section{Chemical Hot Start}

The SSB from E. coli (U.S. Biochemicals) was used in PCR in situ hybridization analysis of HPV 16 DNA in SiHa cells. In these experiments, all reagents, including the Taq DNA polymerase and the SSB, were added to each sample in a 10 $\mu \mathrm{l}$ volume before elevating the temperature of the block of the thermal cycler. The molar equivalent ratio of SSB to total primer $(2 \mu \mathrm{M})$ ranged from $50: 1$ to $1: 210$, calculated from the protein concentration of $2.3 \mu \mathrm{g} / \mu \mathrm{l}$. A molecular mass of $75.6 \mathrm{kD}$ was calculated for the tetramer, as was reported by the SSB supplier and the ability of one SSB tetramer to bind two oligonucleotides under the salt conditions $\left(4.5 \mathrm{~mm} \mathrm{MgCl}_{2}\right.$ and 45 $\mathrm{mm} \mathrm{KCl}$ ) used in this study. ${ }^{(17)}$ (This study examined $\mathrm{NaCl}$; we are assuming the calculations to be equivalent with $\mathrm{KCl}$.) The experiments tested the effect 
TABLE 2 The Effect of Fixation Chemistry and Duration on the Detection of Amplified bcl-2 DNA in PBMs with No Protease Digestion

\begin{tabular}{lcccc}
\hline & \multicolumn{4}{c}{$\begin{array}{c}\text { Detection of bcl-2-amplified DNA (\% positive cells) } \\
\text { (fixative) }\end{array}$} \\
\cline { 2 - 5 } Fixation time & formalin & acetone & $95 \%$ ETOH & Bouin's \\
\hline $5 \mathrm{~min}$ & 5 & 2 & 14 & 0 \\
$15 \mathrm{hr}$ & 0 & 15 & 31 & 0 \\
$39 \mathrm{hr}$ & $\mathrm{ND}$ & 0 & 9 & ND \\
\hline
\end{tabular}

(ND) Not done.

of SSB on the amount of HBV 16-specific DNA synthesis, as only HBV 16 target sequences would be detected.

\section{RESULTS}

Every human PBM will contain two copies of the bcl-2 sequence that is amplifiable by the primers used in this study (Table 1). To determine the importance of fixation chemistry and duration, in situ PCR was performed on PBMs fixed for $5 \mathrm{~min}, 15 \mathrm{hr}$, or $39 \mathrm{hr}$ in acetone, $95 \%$ ethanol, buffered formalin, or Bouin's solution. Each experiment was repeated at least once, and the tabulated values are the mean scores; the range of variation between replicate experiments was from $0 \%$ to $9 \%$, and the highest standard deviation was 9 . The results are compiled in Table 2; Figure 1B shows a representative photomicrographs. Under no condition did all PBMs have detectable amplified $b c l-2$ DNA.

The low and variable detection efficiencies suggested that the fixation conditions may limit cell permeation by a key reagent. To test this hypothesis, the cells were digested with $2 \mathrm{mg} / \mathrm{ml}$ of pepsin for $12 \mathrm{~min}$ prior to in situ PCR. The results for in situ PCR after protease digestion are listed in Table 3 . The percentage of positive cells after protease digestion increased to $100 \%$ after a $15 \mathrm{hr}$ fixation with formalin (Fig. 1C) but decreased to $0 \%$ for the acetone- and ethanol-fixed cells. Cells fixed in Bouin's solution did not demonstrate a positive signal under any reaction conditions. Because cell morphology was poorly preserved after protease digestion and acetone and $95 \%$ ethanol fixation, or after a 5-min formalin fixation, in situ PCR was performed after various fixation times with the pepsin concentration decreased to $20 \mu \mathrm{g} / \mathrm{ml}$ and the time of digestion varied from 1 to $12 \mathrm{~min}$. As shown in Table 3, no increase in the percentage of positive cells with decreased protease digestion time and concentration was evident for the acetone- or ethanol-fixed cells. However, after a 5-min fixation in buffered formalin the positive cells increased from $0 \%$ with a 12 -min digestion with $2 \mathrm{mg} / \mathrm{ml}$ of pepsin to $35 \%$ with a 3 -min digestion with $20 \mu \mathrm{g} / \mathrm{ml}$ pepsin. Note the subsequent decrease to $0 \%$ for the latter if the protease time was increased to $5 \mathrm{~min}$, indicating a narrow optimal threshold.

Alternative explanations for the low detection efficiencies in most experiments were that the DNA was amplified and migrated out of the cell or that the fixation conditions blocked in situ bcl-2 amplification. To test these hypotheses, the amplifying solution was retrieved, its DNA separated on an agarose gel, and DNA sequences homologous to the internal fragment of the bcl-2 gene were analyzed using a ${ }^{32} \mathrm{P}$-labeled probe and Southern hybridization. These blots showed (Fig. 1A) that there was marked specific amplification evident in the solution from the cells fixed for either 5 min or $15 \mathrm{hr}$ in acetone or ethanol with no protease digestion step. No detectable extracellular signal was evident in the solution from the cells fixed in buffered formalin for either $5 \mathrm{~min}$ without digestion (conditions giving $5 \%$ positive cells) or $15 \mathrm{hr}$ with protease digestion (conditions giving $100 \%$ positive cells). To demonstrate that the signal seen in the cells fixed for $15 \mathrm{hr}$ in buffered formalin and then digested was target specific, the digoxigenin-tagged DNA was extracted from the cells after in situ PCR as described previously, ${ }^{(11,15)}$ electrophoresed on an agarose gel, blotted onto a nylon membrane, and analyzed for both immobilized digoxigenin and the ability to hybridize to a ${ }^{32} \mathrm{P}$-labeled probe to the
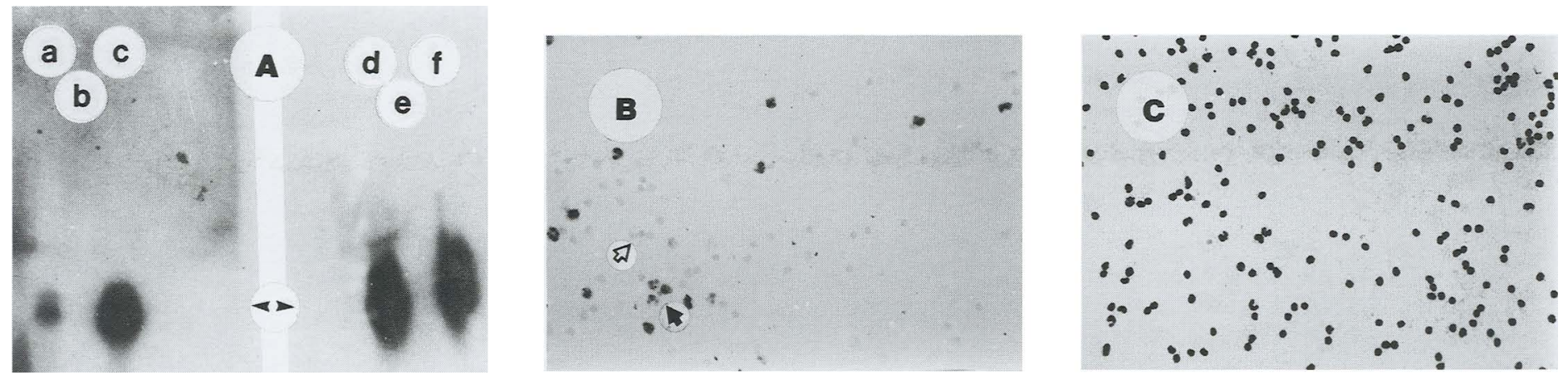

FICURE 1 Effect of fixation conditions on the loss of amplified $b c l-2$ DNA from fixed PBMs. (A) Southern hybridization analysis of the supernatant amplifying solution recovered from selected in situ PCR reactions described in Tables 2 and 3 . Lanes $a$ and $d$ report on acetone fixation for 5 min and $15 \mathrm{hr}$, respectively, without protease treatment (Table 2). Lanes $c$ and $f$ report on $95 \%$ ethanol fixation for $5 \mathrm{~min}$ and $15 \mathrm{hr}$, respectively, without protease treatment (Table 2). Lanes $b$ and $e$ report on formalin fixation for 5 min without proteolysis (Table 2 ) and 15 hr with proteolysis (Table $3)$, respectively. The arrowheads mark the position of the 500-bp band of HindIII digest of $\lambda$ DNA. Note that the amplifying solution from the acetone- and ethanol-fixed cells, but not the formalin-fixed cells, contained the amplified bcl-2 product. (B, $C$ ) Representative microscopic fields for the histochemical analyses corresponding to lanes $b(5 \mathrm{~min}$ formalin, no protease, $5 \%$ positive cells) and $e(15 \mathrm{hr}$ formalin, with protease, $100 \%$ positive cells), respectively. Pale images (open arrow) indicate light-red counterstaining in the absence of the dark-blue phosphatase-linked staining of digoxigenin-tagged localized DNA (solid arrow). 
TABLE 3 The Effect of Fixation Chemistry and Duration on the Detection of Amplified bcl-2 DNA in PBMs with Pepsin Digestion

\begin{tabular}{lcccc}
\hline & \multicolumn{4}{c}{ Detection of bcl-2-amplified DNA (\% positive cells) } \\
(fixative)
\end{tabular}

${ }^{a}$ Compare these data to the first two rows of Table 2.

bcl-2 intervening sequence. A digoxigenin-labeled band, which hybridized to the probe, was evident at the expected size of 504 bp in the cell extract but not the amplifying solution (Fig. 2). Alternatively, a 504-bp digoxigenin band that hybridized to the probe was detected in the amplifying solution and not the cell extract for cells fixed for $5 \mathrm{~min}$ in formalin and proteased for $12 \mathrm{~min}$ at $2 \mathrm{mg} / \mathrm{ml}$ (conditions giving $0 \%$ positive cells; Table 3$)$.

To determine whether the potential depurinating effect of the low $\mathrm{pH}$ (2.0) of the pepsin digestion may have contributed to the results noted with the different fixatives and bcl-2 in PBMs, the experiments with ethanol and buffered formalin-fixed PBMs were redone with proteinase $K$ digestion. No differences were observed in the rate of bcl-2-positive cells when compared with the results of pepsin digestion, including a detection rate of $100 \%$ for $15 \mathrm{hr}$ formalinfixed, proteinase K-digested cells.

When the PCR cycle number was varied from 1 to 20 for PBMs fixed $15 \mathrm{hr}$ in formalin and digested with pepsin, staining was first evident after four cycles and was maximized after seven cycles. The signal was present predominantly in a diffuse way in the nucleus, although at times, perinucleolar staining was evident.

The most advantageous $\mathrm{MgCl}_{2}$ concentration was determined by subjecting the 15-hr fixed/pepsin-digested PBMs to in situ PCR in 0, 1.5, 4.5, 6.0, and $9.0 \mathrm{~mm}$ $\mathrm{MgCl}_{2}$ for 7 cycles and 20 cycles each. No signal was evident when the amplifying solution contained no $\mathrm{MgCl}_{2}$ or $9.0 \mathrm{~mm}$ $\mathrm{MgCl}_{2}$. A weak signal was evident only after 20 cycles for 1.5 and $6.0 \mathrm{~mm} \mathrm{MgCl}_{2}$, compared with the intense signal seen with $4.5 \mathrm{mM}^{\mathrm{mgCl}}$ (Fig. 3). A similar study of Taq DNA polymerase concentra- tion showed that a signal was evident with $2.0 \mathrm{U} / 10 \mu \mathrm{l}$ of amplifying solution but not with 0.4 or $0.2 \mathrm{U} / 10 \mu \mathrm{l}$. Because $2.0 \mathrm{U} / 10 \mu \mathrm{l}$ of Taq DNA polymerase is $\sim 10$ times higher than required for standard PCR, it was reasoned that some of the enzyme might be sequestered on the glass slide. The addition of $1 \mathrm{mg} / \mathrm{ml}$ of bovine serum albumin (BSA), which could block enzyme adsorption, resulting in a strong signal even with 0.2 units of Taq DNA polymerase/10 $\mu$ l (Fig. 3).

Previously, we found that the manual hot start modification described in Materials and Methods enhanced both the sensitivity and specificity of in situ PCR. ${ }^{(7)}$ SSB has been shown to have similar effects on standard PCR. ${ }^{(17,18)}$ In experiments to test the effects of an SSB on target-specific in situ amplification, SiHa cells were employed with primers

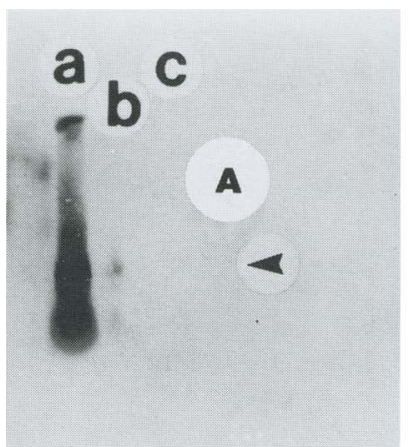

FICURE 2 Specificity of in situ PCR amplification of $b c l-2$ sequences. bcl- 2 target was amplified by either solution-phase hot start PCR (10 ng purified PCR product, nucleotide 2779-3283 bp) or in situ PCR on PBMs formalin-fixed for $15 \mathrm{hr}$ and pepsin digested $(2 \mathrm{mg} / \mathrm{ml}$ for $12 \mathrm{~min})$; in each case, digoxigenin-dUTP was incorporated during 15.cycles using the same cycle parameters. After in situ PCR, total cellular DNA was extracted by phenol/chloroform, then ethanol precipitated. Agarose gel electrophoresis of solution-phase PCR product (lane $a$ of each panel), DNA recovered from fixed cells (lane $b$ of each panel), and the supernatant (lane $c$ of each panel) was followed by blotting onto a nitrocellulose filter. The arrow marks the position of the 500-bp band of HindIII digest of $\lambda$ DNA. (A) Phosphatase-linked histochemical staining of digoxigenin; $(B)$ the autoradiograph after hybridizing the blot to the ${ }^{32} \mathrm{P}$-labeled bcl-2-specific internal probe. Amplified bcl-2 DNA is detectable in each panel in the DNA extracted from the cells but not in the amplifying solution. 

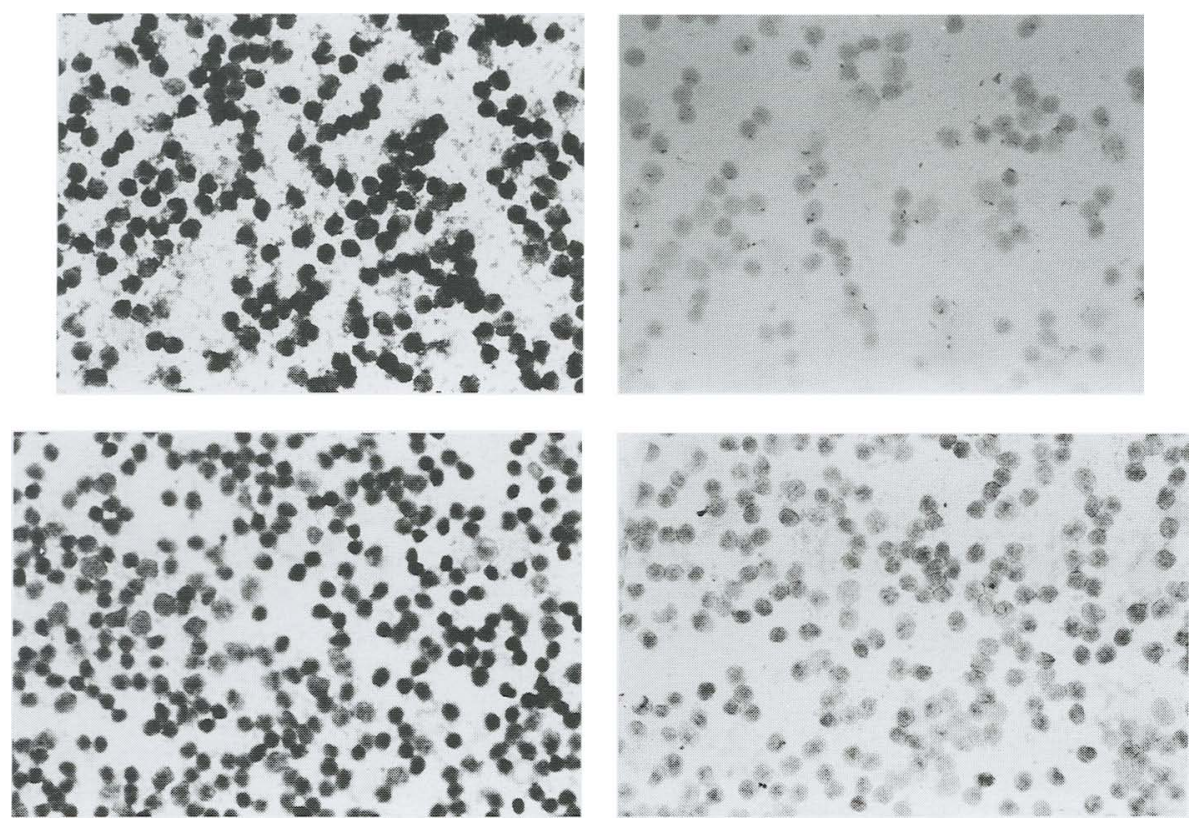

FIGURE 3 Effect of $\mathrm{MgCl}_{2}$ concentration of the detection of amplified bcl-2 DNA in PBMs. At a $\mathrm{MgCl}_{2}$ concentration of $4.5 \mathrm{~mm}$ all PBMs fixed for $15 \mathrm{hr}$ in buffered formalin and digested had an intense signal using in situ PCR and bcl-2 primers (upper left). No signal is evident in PBMs analyzed on the same glass slide if no $\mathrm{MgCl}_{2}$ is added (upper right). The Taq polymerase concentration is 2 units per reaction in each panel. A Taq polymerase concentration of 0.2 units per reaction gives a greatly diminished signal in PBMs fixed for $15 \mathrm{hr}$ in buffered formalin and digested (lower right) compared with that evident with 2.0 units of enzyme (upper left). The signal is enhanced if $2 \mathrm{mg} / \mathrm{ml}$ of BSA is added in a parallel reaction $(0.2$ units of Taq) on the same glass slide (lower left). $\mathrm{MgCl}_{2}$ concentration $=4.5 \mathrm{~mm}$ for lower right and lower left.
The Southern blot presented in Figure 2 demonstrates the specificity of the in situ bcl-2-amplified signal in PBMs. To test the specificity of the in situ PCR technique using the manual hot start modification and another system,

squamous cells from the oral cavity were admixed with the Epstein-Barr virus (EBV)-infected lymphocytes from the Burkitt's lymphoma cell line. Primers specific for EBV were employed. A signal in the squamous cells, which were EBV
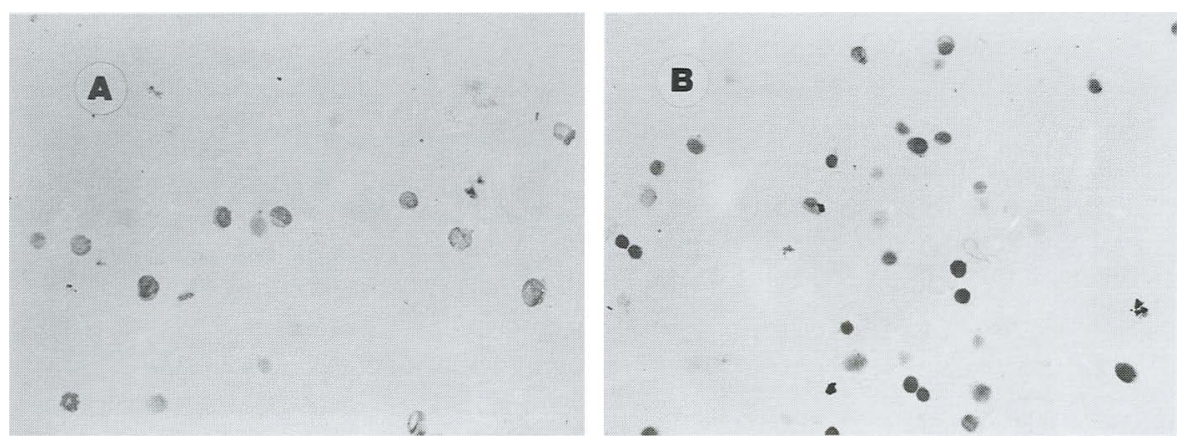

FICURE 4 Effect of SSB on the sensitivity of PCR in situ hybridization. In these experiments, all reagents, including the Taq DNA polymerase and the SSB were added to each sample in a 10- $\mu$ l volume before elevating the temperature of the block of the thermal cycler. No hybridization signal is evident in SiHa cells that contain one copy of HPV 16 per cell after in situ hybridization analysis with a digoxigenin-labeled HPV 16 probe after PCR if SSB is added at a molar equivalent ratio to primer of $1: 210(A)$; a signal is evident with the manual hot start modification (not shown here) ${ }^{(7)}$ A hybridization signal is evident if SSB is added at a ratio of $1: 21$ in a parallel experiment done on the same glass slide $(B)$. negative, must represent nonspecific DNA synthesis. The results are provided in Table 5 . Note the absence of any signal in the squamous cells and the similar results with the different fixatives when compared with the data for the PBMs and the bcl-2-specific primers (Tables 2 and 3 ). A representative photograph is presented in Figure 6.

\section{DISCUSSION}

This study characterized conditions that enhance in situ detection of PCR-amplified DNA. In this study only buffered formalin fixation for $15 \mathrm{hr}$ with protease digestion allowed detection of amplified DNA in every cell that contained the target. The $\mathrm{MgCl}_{2}$ concentration of $4.5 \mathrm{~mm}$ maximized signal in the cellular preparations for bcl-2 detection. The conditions of formalin fixation, protease digestion, and $4.5 \mathrm{mM} \mathrm{MgCl}_{2}$ outlined here appear to be a generalized protocol for in situ PCR as one obtains the strongest signal under these conditions for a variety of primers and targets that ranged in size from 115 to $833 \mathrm{bp}$ and included HPV 6, 11,16 , HIV-1, EBV, and cDNAs for measles, tumor necrosis factor, and other human mRNAs. ${ }^{(7-9,11,12)}$ The need for relatively high concentrations of Taq DNA polymerase likely reflects, at least in part, sequestration of the enzyme on silanized glass, as shown by signal enhancement at lower enzyme concentrations with the addition of BSA.

The ability to PCR-amplify sequences from tissues fixed in either ethanol or acetone is well documented. Greer et al. ${ }^{(13)}$ demonstrated that successful PCR was more likely for DNA extracted from tissues fixed in either acetone or ethanol than for DNA subjected to buffered formalin. However, the present study showed that amplification occurred in ethanol- and acetone-fixed cells, but PCR product was primarily detectable in the amplifying solution. Thus, neither ethanol nor acetone fixation will prevent migration of the amplified product out of the nucleus, probably because proteins and, perhaps, nucleic acids are not crosslinked. In contrast, prolonged formalin fixation was clearly able to create a physical barrier to prevent migration of PCR product. Formalin (i.e., formaldehyde) extensively polymerizes proteins and can cross-link nucleic acids ${ }^{(19-22)}$ which probably is the essential step for limiting PCR product diffusion. The extent of mi- 


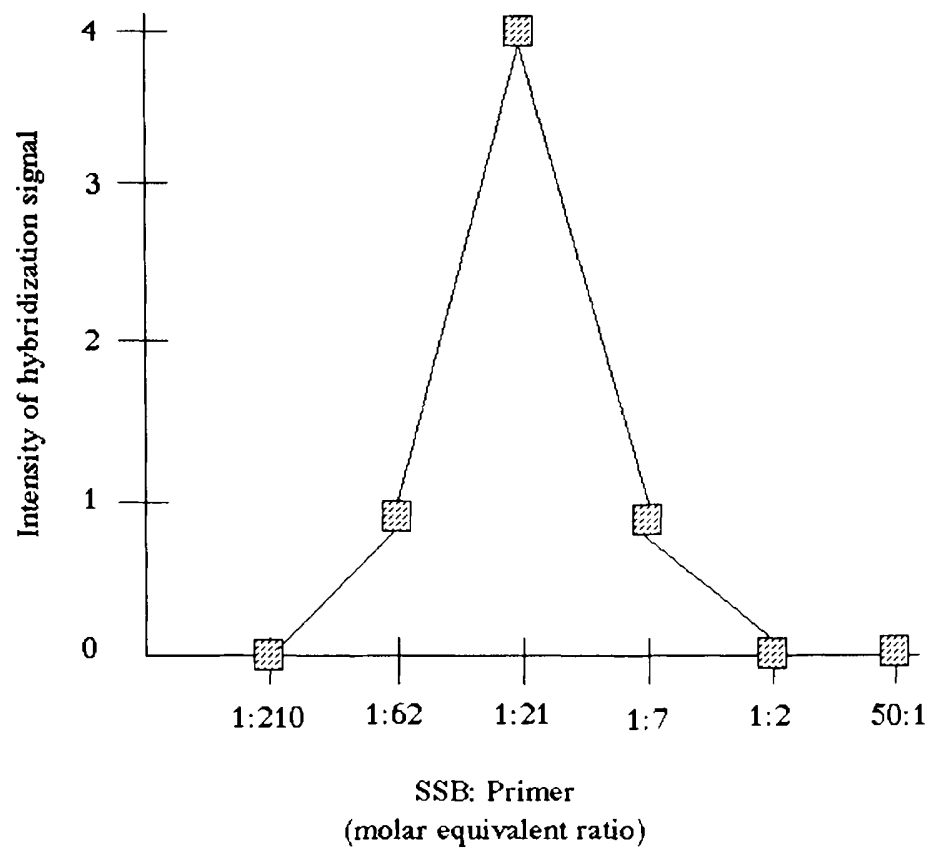

FICURE 5 Effect of SSB concentration on the detection of HPV 16 DNA by PCR in situ hybridization without the manual hot start modification. The presence and intensity of the hybridization signal evident with the addition of SSB at different molar equivalent ratios to the total primer concentration $(2 \mu \mathrm{M})$ is depicted. The signal intensity was visually graded by one of us (G.J.N.) from 0 (no signal) to 4 (intense) without knowledge of the SSB concentration.

gration limitation is striking based on several observations. First, amplified cDNAs corresponding to human mRNAs localize to specific cytoplasmic and subnuclear compartments. ${ }^{(12,21)}$ Second, amplified HPV 16 DNA is detectable in most paraffin-embedded SiHa cells even after the nucleus is sectioned; presum-

TABLE 4 The Effect of Manual Hot Start on the in Situ PCR Detection Rate Using Nonsense (Measles-specific) Primers on PBMs

\begin{tabular}{lc}
\hline $\begin{array}{l}\text { Fixation time/ } \\
\text { pepsin conditions }\end{array}$ & $\begin{array}{c}\text { Percentage } \\
\text { positive cells }\end{array}$ \\
\hline $5 \mathrm{~min} / \mathrm{no}$ protease & 0 \\
$5 \mathrm{~min} / 20 \mu \mathrm{g} / \mathrm{ml}, 2 \mathrm{~min}^{\mathrm{a}}$ & 0.02 \\
$15 \mathrm{hr} / \mathrm{no} \mathrm{protease}$ & 0 \\
$15 \mathrm{hr} / 2 \mathrm{mg} / \mathrm{ml}, 12 \mathrm{~min}^{\mathrm{a}}$ & $0.02^{\mathrm{b}}$ \\
$15 \mathrm{hr} / 2 \mathrm{mg} / \mathrm{ml}, 30 \mathrm{~min}$ & 80 \\
\hline
\end{tabular}

The numbers were based on $\sim 10,000-15,000$ cells.

${ }^{a}$ The detection rate was 0 if the annealing/ extension temperature during cycling was increased from $55^{\circ} \mathrm{C}$ to $65^{\circ} \mathrm{C}$

${ }^{b}$ The detection rate for 15 -hr formalin-fixed cells digested for 12 min with pepsin without the manual hot start modification (all reagents added before temperature of block was elevated) was $77 \%$. ably some positive cells still contained the one copy of HPV 16 after part of their nuclei is removed by the microtome blade. ${ }^{(7,9)}$ Third, no amplified product is detectable in the amplifying solution after in situ PCR with formalin-fixed, digested cells when all of the cells have intense nuclear staining.

Formalin cross-linkage, which we theorize suppresses migration of the amplified product, apparently also can inhibit

TABLE 5 Effect of Different Fixatives on the Detection of PCR-Amplified DNA Using EBV-Specific Primers in a Mixture of an EBV-Positive Cell Line (Burkitt's Lymphoma) and Viral-negative Squamous Cells

\begin{tabular}{lcc}
\hline & \multicolumn{2}{c}{$\begin{array}{c}\text { Detection of } \\
\text { amplified DNA } \\
\text { (\% positive cells) }\end{array}$} \\
\cline { 2 - 3 } Fixative/time & $\begin{array}{l}\text { Burkitt's } \\
\text { lymphoma }\end{array}$ & $\begin{array}{l}\text { Squamous } \\
\text { cells }\end{array}$ \\
\hline Acetone $/ 5 \mathrm{~min}$ & 9 & 0 \\
Acetone $/ 15 \mathrm{hr}$ & 16 & 0 \\
$95 \%$ Ethanol $/ 5 \mathrm{~min}$ & 20 & 0 \\
$95 \%$ Ethanol $/ 15 \mathrm{hr}$ & 22 & 0 \\
Formalin $/ 15 \mathrm{hr} /$ & & 0 \\
protease & 100 & 0 \\
\hline aProtease is pepsin at $2 \mathrm{mg} / \mathrm{ml}$ for $12 \mathrm{~min}$.
\end{tabular}

entry of at least one key reagent, necessitating a protease digestion step. This effect is evident even after $5 \mathrm{~min}$ of fixation, as the detection rate under these conditions without proteolysis was $\sim 5 \%$ and no product was detectable in the amplifying solution. Protease digestion could not increase the detection rate to $100 \%$ for in situ PCR of cells fixed for 5 min in formalin; the detection of PCR product in the amplifying solution after longer pepsin digestion for cells fixed for 5 min suggested that too few cross-links had been formed to create a robust migration barrier. It appears that protease digestion may be a necessary step with in situ PCR when cross-linking fixatives are used.

Both solution phase and in situ PCR suffer from several side reactions that compete with target-specific amplification. Nonspecific DNA synthesis can follow extension of primers annealed to nontarget sequences ("mispriming") and extension of primers onto one another's sequence to form primer oligomers; the latter process needs no additional DNA. ${ }^{(3,8)}$ We have shown previously that manual hot start PCR, a method whereby at least one reagent is withheld until the reaction temperature has reached at least $55^{\circ} \mathrm{C}$ at the initiation of cycling, greatly reduces side reactions and concomitantly increases the yield of specific product in situ. ${ }^{(8)}$ In the prior study, ${ }^{(8)}$ where PBMs were mixed with $\mathrm{SiHa}$ cells and primers specific for HPV 16 were employed, we demonstrated that with standard in situ PCR both the PBMs and SiHa cells incorporated labeled nucleotide. With the hot start modification, labeled nucleotide was incorporated only in the SiHa cells. In an analogous experiment, PBMs were mixed with measles-infected HeLa cells, which can be differentiated from the PBMs by their multiple nuclei. Using reverse transcriptase in situ PCR with direct incorporation and measles-specific primers, it was shown that only the HeLa cells incorporated signal under the optimal conditions described in this study. ${ }^{(12,21)}$ Equivalent results were obtained in this study using squamous cells and lymphocytes infected by EBV and EBV-specific primers. These observations all highlight the specificity of the PCR product synthesized inside cells. The specificity was documented by Southern blot hybridization with an internal probe of the PCR-amplified bcl-2 DNA 


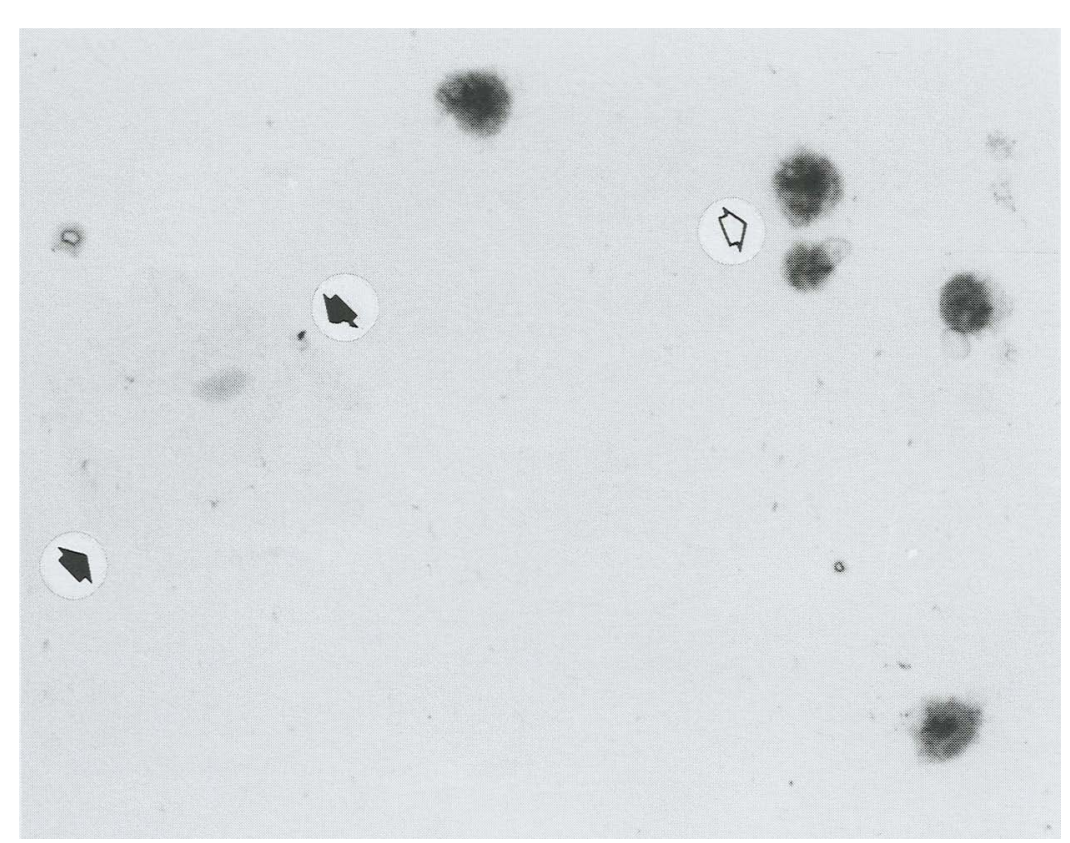

FIGURE 6 The specificity of in situ PCR as demonstrated by cell-mixing experiments. An EBVpositive Burkitt's lymphoma cell line was mixed with viral-negative oral squamous cells, fixed for $15 \mathrm{hr}$ in formalin, and digested in pepsin $(2 \mathrm{mg} / \mathrm{ml})$ for $12 \mathrm{~min}$. With the manual hot start maneuver and EBV-specific primers, all of the lymphocytes had a signal with direct incorporation of digoxigenin-labeled nucleotide into the PCR product (open arrows). None of the squamous cells, which are easily distinguished cytologically by their ample cytoplasm (solid arrows), had nuclei with a detectable signal.

extracted from the PBMs after in situ PCR (Fig. 2). The present study shows that although nonspecific incorporation can occur in hot start in situ PCR, it is easily limited to a rate of $\sim 1 / 5000$ cells as compared with a rate of $>50 \%$ when this modification is omitted. This rate was dependent on the annealing/extension temperature, whereas the rate of target-specific amplification was not temperature dependent up to $65^{\circ} \mathrm{C}$. However, it is unclear why extended protease digestion should increase nonspecific DNA synthesis so dramatically, even at the higher annealing temperatures. We have noted a similar high, nonspecific incorporation rate for in situ PCR in formalin-fixed tissue sections even after $12 \mathrm{~min}$ of proteolysis with nonsense measles primers (G.J. Nuovo, unpubl.). The reasons for these observations will require further study.

The enhances sensitivity that is the hallmark of hot start PCR was evident without the manual hot start maneuver when an optimal concentration of SSB was added to the amplifying solution. At a molar equivalent ration (to total primers) of $1: 21$, the SSB may inhibit mispriming without binding so much primer that specific amplification is blocked. The complete blockage of specific amplification at SSB concentrations near and above the primer concentration is the expected result of primer sequestration. The failure of specific amplification at very low SSB concentrations should occur if side reactions overwhelm the specific reaction. We documented this occurrence in PCR and PCR in situ hybridization when manual hot start is omitted. ${ }^{(7)}$

\section{ACKNOWLEDGMENTS}

We greatly appreciate the material assistance and advice from Drs. John Sninsky (Roche Molecular Systems), Larry Haff, and John Atwood (Perkin-Elmer Cetus Corporation), and Brian Holaway (Boehringer Mannheim). We are indebted to Quin Chou (Berlex Biosciences) for pioneering unpublished study of SSB improvements of PCR while at Cetus Corporation. Dr. Ernest Kawasaki (Procept, Inc.) kindly provided the $b c l-2$ primers based on research he directed at Cetus Corporation. We greatly appreciate the strong interest of Mr. Salim B. Lewis in the in situ PCR technology. This work was supported by a grant to G.J.N. from the Lewis Foundation.

\section{REFERENCES}

1. Crum, C.P., G.J. Nuovo, D. Friedman, and S.J. Silverstein. 1988. A comparison of biotin and isotope labeled ribonucleic acid probes for in situ detection of HPV 16 ribonucleic acid in genital precancers. $L a b$. Invest. 58: 354-359.

2. Nuovo, G.J. 1989. A comparison of different methodologies (biotin based and $35 \mathrm{~S}$ based) for the detection of human papillomavirus DNA. Lab. Invest. 61:471-476.

3. Chou, Q., M. Russell, D.E. Birch, J. Raymond, and W. Bloch. 1992. Prevention of pre-PCR mis-priming and primer dimerization improves low-copy-number amplifications. Nucleic Acids Res. 20: 1717 1723.

4. Saiki, R.K., S. Scharf, F. Faloona, K.B. Mullis, G.T. Horn, H.A. Erlich, and N. Arnheim. 1985. Enzymatic amplification of Beta-globulin genomic sequences and restriction site analysis for diagnosis of sickle cell anemia. Science 230: 1350 1354.

5. Chiu, K.P., S.H. Cohen, D.W. Morris, and G.W. Jordan. 1992. Intracellular amplification of proviral DNA in tissue sections using the polymerase chain reaction. $J$. Histochem. Cytochem. 40: 333-341.

6. Haase, A.T., E.F. Retzel, and K.A. Staskus. 1990. Amplification and detection of lentiviral DNA inside cells. Proc. Natl. Acad. Sci. 87: 4971-4975.

7. Nuovo, G.J., F. Gallery, P. MacConnell, J. Becker, W. Bloch. 1991. An improved technique for the in situ detection of DNA after polymerase chain reaction amplification. Am. J. Pathol. 139: 12391244.

8. Nuovo, G.J., P. MacConnell, A. Forde, and P. Delvenne. 1991. Detection of human papillomavirus DNA in formalin fixed tissues by in situ hybridization after amplification by PCR. Am. I. Pathol. 139: 847854.

9. Nuovo, G.J., J. Becker, P. MacConnell, M. Margiotta, S. Comite, and H. Hochman. 1992. Histological distribution of PCRamplified HPV 6 and 11 DNA in penile lesions. Am. J. Surg. Pathol. 16: 269-275.

10. Bagasra, O., S.P. Hauptman, H.W. Lischer, M. Sachs, and R.J. Pomerantz. 1992. Detection of human immunodeficiency virus type 1 provirus in mononuclear cells by in situ polymerase chain reaction. $N$. Engl. J. Med. 326: 1385-1391.

11. Nuovo, G.J., M. Margiotta, P. MacConnell, and J. Becker. 1992. Rapid in situ detection of PCR-amplified HIV-1 DNA. Diagn. Mol. Pathol. 1: 98-102.

12. Nuovo, G.J. 1992. PCR in situ hybridiza- 
tion: Protocols and applications. Raven Press, New York.

13. Greer, C.E., S.J. Peterson, N.B. Kiviat, and M.M. Manos. 1991. PCR amplification from paraffin-embedded tissues: Effects of fixative and fixative times. Am. J. Clin. Pathol. 95: 117-124.

14. Shibata, D.K., N. Arnheim, and W.J. Martin. 1988. Detection of human papilloma virus in paraffin-embedded tissue using the polymerase chain reaction. J. Exp. Med. 167: 225-230.

15. Nuovo, G.J., M.M. Darfler, C.C. Impraim, and S.E. Bromley. 1991. Occurrence of multiple types of human papillomavirus in genital tract lesions: Analysis by in situ hybridization and the polymerase chain reaction. Am. J. Pathol. 58: 518-523.

16. Nuovo, G.J. 1992. Determination of HPV type by in situ hybridization analysis: A comparative study with Southern blot hybridization and the polymerase chain reaction. J. Histotech. 15: 99-104.

17. Lohman, T.M. and W. Bujalowski. 1988. Negative cooperativity within individual tetramers of Escherichia coli single stranded binding protein is responsible for the transition between the (SSB) ${ }_{35}$ and $(\mathrm{SSB})_{56}$ DNA binding modes. Biochemistry 27: 2260-2265.

18. Oshima, R.G. 1992. Single-stranded DNA protein facilitates amplification of genomic sequences by PCR. BioTechiques 13: 188-193.

19. Dubeau, L., L.A. Chandler, J.R. Gralow, P.W. Nichols, and P.A. Jones. 1986. Southern blot analysis of DNA extracted from formalin fixed pathology specimens. Cancer Res. 46: 2964-2970.

20. Nuovo, G.J. and S.J. Silverstein. 1988. Comparison of formalin, buffered formalin, and Bouin's fixation on the detection of human papillomavirus DNA from genital lesions. Lab. Invest. 59: 720-724.

21. Nuovo, G.J., G. Gorgone, P. MacConnell, and P. Goravic. 1992. in situ localization of PCR-amplified human and viral cDNAs. PCR Methods Applic. 2: 117-123.

22. Nuovo, G.J. 1989. Buffered formalin is the superior fixative for the detection of human papillomavirus DNA by in situ hybridization analysis. Am. J. Pathol. 134: 837-842.

23. Rozenblatt, S., O. Eizenberg, R. Ben-Levy, V. Lavie, and W.J. Bellini. 1985. Sequence homology within the morbilliviruses. $J$. Virol. 53: 684-690.

24. Saito, I., B.O. Servnius, T. Compton, and R.I. Fox. 1989. Detection of Epstein-Barr virus DNA by polymerase chain reaction in blood and tissue biopsies from patients with Sjogren's syndrome. J. Exp. Med. 169: 1291-1298. 


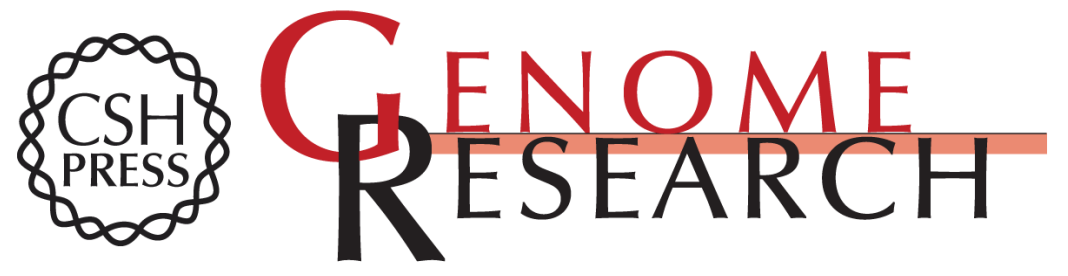

\section{Importance of different variables for enhancing in situ detection of PCR-amplified DNA.}

G J Nuovo, F Gallery, R Hom, et al.

Genome Res. 1993 2: 305-312

Access the most recent version at doi:10.1101/gr.2.4.305

References This article cites 23 articles, 5 of which can be accessed free at:

http://genome.cshlp.org/content/2/4/305.full.html\#ref-list-1

License

Email Alerting Receive free email alerts when new articles cite this article - sign up in the box at the Service top right corner of the article or click here.

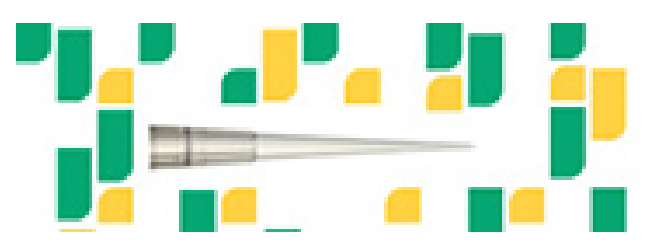

Focused on your science.

To subscribe to Genome Research go to:

https://genome.cshlp.org/subscriptions 